\title{
PENGARUH FAKTOR MAKROEKONOMI TERHADAP TOTAL NILAI EMISI SUKUK KORPORASI DI INDONESIA (PERIODE JANUARI 2013-DESEMBER 2017)'
}

\author{
Mohamad Arif Wahyudi \\ Departemen Ekonomi Syariah-Fakultas Ekonomi dan Bisnis-Universitas Airlangga \\ Email: mohamad-a-w-11@feb.unair.ac.id
}

\author{
Atina Shofawati \\ Departemen Ekonomi Syariah-Fakultas Ekonomi dan Bisnis-Universitas Airlangga \\ Email: atina-o@feb.unair.ac.id
}

\begin{abstract}
:
This research aims to analyze the influence of inflation, rupiah exchange rate and SBIS reward on the total value of corporate Sukuk emissions in Indonesia. All data used in this research obtained from Bank Indonesia, Kemendag Indonesia and Otoritas Jasa Keuangan. This research used the quantitative approach method. The data analysis method used in this research is multiple linear regression analysis. Based on the result, this research showed that simultaneously inflation, rupiah exchange rate and SBIS reward had significant effect on the total value of corporate Sukuk emissions. The partial test showed that inflation and SBIS reward had significant and negative effect on the total value of corporate Sukuk emissions, while the rupiah exchange rate has significant and positive effect on the total value of corporate Sukuk emissions in Indonesia for the period of January 2013 to December 2017.
\end{abstract}

Keywords: Corporate Sukuk, Inflation, Rupiah Exchange Rate, Certificate of Sharia Indonesian Bank (SBIS)

\section{PENDAHULUAN}

\section{Latar Belakang}

Islam sangat menganjurkan umatnya untuk melakukan aktifitas ekonomi (muamalah) dengan cara yang benar dan baik, serta melarang penimbunan barang, atau membiarkan harta (uang) tidak produktif, sehingga aktifitas ekonomi yang dilakukan dapat meningkatkan ekonomi umat. Dengan kata lain, investasi itu penting dilakukan oleh umat Islam. Beberapa tahun terakhir memang terlihat trend dari masyarakat muslim untuk lebih peduli pada peluang investasi, terlebih yang sesuai dengan Syariah. Investasi adalah suatu kegiatan seseorang dalam memfungsikan kekayaan untuk memperoleh pendapatan atau keuntungan lainnya dalam jangka panjang. Pengertian lain menyebutkan investasi bisa diartikan sebagai suatu tindakan untuk mengembangkan nilai aset yang dimiliki. Investasi dapat dilakukan dalam sektor riil maupun keuangan (Kholis, 2010).

Menurut Manan (2009:23) secara umum investasi terdiri dari 2 hal yaitu investasi pada riil asset dan financial asset. Investasi pada riil asset yaitu investasi pada sektor aset yang nyata seperti tanah, bangunan, emas, dan lainnya, sedangkan financial asset merupakan investasi pada aset keuangan berupa surat berharga, pasar vang, maupun pasar modal.

\footnotetext{
${ }^{1}$ Jurnal ini merupakan bagian dari skripsi Mohamad Arif Wahyudi, NIM: 041114152 , yang diuji pada tanggal 18 Juli 2018.
} 
Wahyudi, et al/Jurnal Ekonomi Syariah Teori dan Terapan Vol. 6 No. 3 Maret 2019: 461-476 PENGARUH FAKTOR MAKROEKONOMI TERHADAP TOTAL NILAI EMISI SUKUK KORPORASI DI INDONESIA (PERIODE JANUARI 2013-DESEMBER 2017)

Salah satu instrument yang di tawarkan di pasar modal syariah, sebagai bentuk investasi non-riil bagi investor adalah sukuk.Sukuk merupakan surat berharga yang berisi kontrak (akad) pembiayaan berdasarkan prinsip syariah. Sukuk ini dikeluarkan oleh lembaga/institusi/organisasi baik swasta maupun pemerintah kepada investor (sukuk holder). Sukuk mewajibkan pihak yang mengeluarkan untuk membayar pendapatan kepada investor berupa bagi hasil atau margin atau fee selama masa akad. Emiten wajib membayar kembali dana investasi kepada investor pada saat jatuh tempo (Ryandono, 2009:350).

Sukuk berbeda dengan obligasi, perbedaan sukuk dan obligasi secara mendasar dapat dilihat dari tidak digunakannya sistem bunga. Sistem bunga dalam ajaran Islam sangat dilarang karena merupakan riba, segala transaksi yang mengandung unsur riba sangat diharamkan dalam syariat Islam. Hal tersebut dijelaskan dalam QS.AIBaqarah ayat 278.

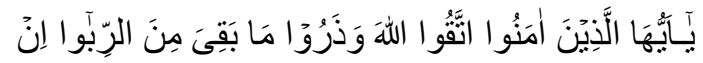

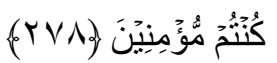

Menurut Quraish Shihab dalam Tafsir Al-Misbah (2002: 597) ayat tersebut menjelaskan tentang perbedaan antara yang melakukan praktek riba, dengan yang beriman dan beramal saleh, melaksanakan shalat dan menunaikan zakat, maka sungguh tepat bila ayat ini mengundang orang-orang beriman yang selama ini masih memiliki keterkaitan dengan praktek riba agar segera meninggalkannya untuk menghindari siksa atau jatuhnya sanksi dari Allah. Jika seseorang melakukan praktek riba, maka bermakna ia tidak percaya kepada Allah dan janji-janji-Nya.

Sukuk terbagi menjadi dua jenis yaitu sukuk korporasi, sukuk yang diterbitkan oleh perusahaan berdasarkan prinsip syariah dan sukuk yang diterbitkan oleh negara yang lebih dikenal dengan Surat Berharga Syariah Negara (SBSN). Menurut Fatwa DSN-MUI No.69/DSNMUI/VI/2008 Tentang Surat Berharga Syariah Negara, Surat Berharga Syariah Negara (SBSN) atau dapat disebut sukuk negara, adalah surat berharga negara yang diterbitkan berdasarkan prinsip syariah, sebagai bukti atas bagian kepemilikan aset SBSN, baik dalam mata vang rupiah maupun valuta asing.

Menurut data yang diperoleh dari Otoritas Jasa Keuangan (OJK). Total nilai emisi sukuk korporasi pada periode penelitian, mengalami peningkatan tiap tahunnya.

\section{Tabel 1.}

Total Nilai Emisi Sukuk Korporasi di Indonesia Periode Januari 2013-Desember 2017

\begin{tabular}{|c|c|c|}
\hline Tahun & $\begin{array}{c}\text { Total Nilai Emisi } \\
\text { Sukuk Korporasi } \\
\text { (Rp Triliun) }\end{array}$ & $\begin{array}{c}\text { Jumlah Emisi } \\
\text { Sukuk }\end{array}$ \\
\hline 2013 & $11.994,4$ & 64 \\
\hline 2014 & $12.917,4$ & 71 \\
\hline 2015 & 16.144 & 87 \\
\hline 2016 & $20.425,4$ & 100 \\
\hline
\end{tabular}


Wahyudi, et al/Jurnal Ekonomi Syariah Teori dan Terapan Vol. 6 No. 3 Maret 2019: 461-476 PENGARUH FAKTOR MAKROEKONOMI TERHADAP TOTAL NILAI EMISI SUKUK KORPORASI DI INDONESIA (PERIODE JANUARI 2013-DESEMBER 2017)

\begin{tabular}{|l|c|c|}
\hline 2017 & $26.394,9$ & 137 \\
\hline
\end{tabular}

Sumber: www.ojk.go.id Data diolah 2018

Berdasarkan data pada Tabel 1 dapat dilihat bahwa selama periode penelitian, pada tahun 2013 total nilai emisi sukuk korporasi sebasar 11.994,4 triliun. Total nilai emisi sukuk korporasi terus mengalami peningkatan sampai tahun 2017 menjadi sebesar 26.394,9 triliun (www.ojk.go.id).

Pada penelitian ini objek yang digunakan adalah total nilai emisi sukuk korporasi. Alasan dipilinnya total nilai emisi sukuk korporasi adalah karena total nilai emisi sukuk korporasi berkembang secara lamban berbeda dengan total nilai emisi Sertifikat Berharga Syariah Negara (SBSN), dalam Ardiansyah dan Lubis (2017) menyebutkan pada tahun 2015, total nilai emisi SBSN mencapai 118.5 triliun dari pertama diterbitkan pada tahun 2008, sedangkan pada tahun yang sama total nilai emisi sukuk korporasi sebesar 15.9 triliun sejak pertama diterbitkan pada tahun 2002. Penelitian ini ingin mengetahui seberapa besar variabel makroekonomi yaitu inflasi, nilai tukar rupiah dan imbalan SBIS mempengaruhi total nilai emisi sukuk korporasi.

Kestabilan makroekonomi dalam negeri sangat diperlukan bagi kondisi instrumen surat berharga yang ada di pasar modal syariah Indonesia, khususnya penerbitan sukuk, perubahan kondisi makroekonomi dapat memberi pengaruh terhadap pasar modal syariah. Tabel 2 mengambarkan kondisi makroekonomi selama periode penelitian.
Tabel 2. Indikator Makroekonomi Periode 2013-2017

\begin{tabular}{|c|c|c|c|c|c|}
\hline Indikator & 2013 & 2014 & 2015 & 2016 & 2017 \\
\hline Inflasi $(\%)$ & $8,38 \%$ & $8,36 \%$ & $3,35 \%$ & $3,02 \%$ & $3,61 \%$ \\
\hline Kurs (Rp) & $12.189,00$ & $12.440,00$ & $13.795,00$ & $13,436,00$ & $13.548,00$ \\
\hline Imbalan & $7,21695 \%$ & $6,90129 \%$ & $7,10 \%$ & $5,90 \%$ & $5,20898 \%$ \\
SBIS (\%) & & & & & \\
\hline
\end{tabular}

Sumber: $\quad$ www.bi.go.id dan www.kemendag.go.id (data peneliti)

Pada Tabel 2 menjelaskan pada saat periode penelitian,kondisi inflasi di Indonesia terus mengalami penurunan dan meningkat pada tahun 2017 sebesar $3.61 \%$. Rupiah mengalami apresiasi tertinggi pada tahun 2013 sebesar (Rp 12.189,00/USD), terdepresiasi sebesar (Rp 13.795,00/USD) pada tahun 2015. Imbalan SBIS tertinggi terjadi pada tahun 2013, yaitu sebesar $7.2 \%$ dan terendah pada tahun 2017 , sebesar 5.2\%.

Pentingnya pengendalian inflasi didasarkan pada pertimbangan bahwa inflasi yang tinggi dan tidak stabil memberikan dampak negatif kepada kondisi sosial ekonomi masyarakat. Inflasi yang tidak stabil akan menciptakan ketidakpastian (uncertainty) bagi pelaku ekonomi dalam mengambil keputusan. Pengalaman empiris menunjukkan bahwa inflasi yang tidak stabil akan menyulitkan keputusan masyarakat dalam melakukan konsumsi, investasi dan produksi yang pada akhirnya akan menurunkan pertumbuhan ekonomi (inflasi :www.bi.go.id).

Nilai tukar rupiah terhadap USD menjadi salah satu faktor makro ekonomi yang mempengaruhi jumlah sukuk 
Wahyudi, et al/Jurnal Ekonomi Syariah Teori dan Terapan Vol. 6 No. 3 Maret 2019: 461-476 PENGARUH FAKTOR MAKROEKONOMI TERHADAP TOTAL NILAI EMISI SUKUK KORPORASI DI INDONESIA (PERIODE JANUARI 2013-DESEMBER 2017)

korporasi yang beredar dan mempengaruhi terhadap risiko investasi. Peningkatan nilai mata vang suatu negara terhadap mata vang negara lain berakibat harga barang-barang negara lain menjadi mahal. Dari sudut pandang pasar modal maka penurunan nilai mata vang suatu negara akan menjadikan return dan jumlah investasi pada negara tersebut menjadi turun juga bila diukur dengan mata vang negara lain (Bakri, 2004).

Faktor lain yang mempengaruhi pertumbuhan sukuk korporasi adalah imbalan yang diberikan oleh SBIS. Adanya imbalan yang diberikan oleh SBIS memberi pertimbangan kepada investor untuk menginvestasikan dananya pada SBIS. Semakin tinggi imbalan hasil yang didapat dari SBIS mengakibatkan investor lebih tertarik untuk menanamkan dananya di Bank daripada menerbitkan surat hutang berupa sukuk.

Berdasarkan uraian latar belakang masalah diatas maka penelitian ini mengambil judul "Pengaruh Inflasi, Nilai Tukar Rupiah, dan Imbalan SBIS Terhadap PenerbitanSukukKorporasi di Indonesia (Periode Januari 2013-Desember 2017)".

\section{Rumusan Masalah}

Berdasarkan latar belakang masalah, maka dapat dirumuskan permasalahan berikut:

1. Apakah inflasi, nilai tukar rupiah dan imbalan SBIS berpengaruh secara parsial terhadap total nilai emisi sukuk korporasi di Indonesia periode Januari 2013-Desember 2017?
2. Apakah inflasi, nilai tukar rupiah dan imbalan SBIS berpengaruh secara simultan terhadap total nilai emisi sukuk korporasi di Indonesia periode Januari 2013-Desember 2017?

\section{Tujuan Penelitian}

Berdasarkan rumusan masalah diatas, maka tujuan penelitian ini adalah:

1. Untuk mengetahui pengaruh inflasi, nilai tukar rupiah dan imbalan SBIS secara parsial terhadap total nilai emisi sukuk korporasi di Indonesia periode Januari 2013-Desember 2017.

2. Untuk mengetahui pengaruh inflasi, nilai tukar rupiah dan imbalan SBIS secara simultan terhadap total nilai emisi sukuk korporasi di Indonesia periode Januari 2013-Desember 2017.

\section{LANDASAN TEORI}

Menurut Ryandono

(2009:350) sukuk merupakan surat berharga yang berisi kontrak (akad) pembiayaan berdasarkan prinsip syariah. Sukuk ini dikeluarkan oleh lembaga/institusi/organisasi baik swasta maupun pemerintah kepada investor (sukuk holder). Sukuk mewajibkan pihak yang mengeluarkan untuk membayar pendapatan kepada investor berupa bagi hasil atau margin atau fee selama masa akad. Emiten wajib membayar kembali dana investasi kepada investor pada saat jatuh tempo.

Penerbitan sukuk pada umumnya memerlukan SPV (Special Purpose Vehicle) sebagai penerbit, sedangkan obligasi diterbitkan secara langsung oleh obligor. SPV (Special Purpose Vehicle) 
Wahyudi, et al/Jurnal Ekonomi Syariah Teori dan Terapan Vol. 6 No. 3 Maret 2019: 461-476 PENGARUH FAKTOR MAKROEKONOMI TERHADAP TOTAL NILAI EMISI SUKUK KORPORASI DI INDONESIA (PERIODE JANUARI 2013-DESEMBER 2017)

adalah badan hukum yang didirikan khusus untuk kepentingan penerbitan sukuk yang memiliki fungsi sebagai penerbit sukuk, counterpart pemerintah dalam transaksi pengalihan aset dan bertindak sebagai wali amanat (trustee) yang mewakili kepentingan investor. Terdapat beberapa pihak yang saling terkait pasti akan terlibat dalam penerbitan sukuk, pihak-pihak tersebut antara lain: 1) Obligor, 2) Investor, 3) Special Purpose Vehicle (SPV), 4)Trustee, 5) Appraiser, 6) Custody, 7) Syariah Advisor, dan 8) Arranger (Sunarsih, 2008:38).

Jenis sukuk ditinjau dari
penerbitnya dibedakan menjadi dua
yaitu:

1. Sertifikat Berharga Syariah Negara (SBSN), dalam Fatwa DSN-MUI No.69/DSN-MUI/VI/2008 Tentang Surat Berharga Syariah Negara, Surat Berharga Syariah Negara (SBSN) atau dapat disebut sukuk negara, adalah surat berharga negara yang diterbitkan berdasarkan prinsip syariah, sebagai bukti atas bagian kepemilikan aset SBSN, baik dalam mata uang rupiah maupun valuta asing.

2. Sukuk korporasi adalah surat investasi syariah yang diterbitkan oleh perusahaan atau emiten sebagai bukti penyertaan modal investor terhadap perusahaan atas suatu aset atau proyek tertentu.

Hidayat (2011: 114-145), membagi jenis sukuk berdasarkan akadnya, yaitu: 1) Sukuk Mudharabah, 2) Sukuk Murabahah,
3) Sukuk Musyarakah, 4) Sukuk Salam, 5) Sukuk Istishna', dan 6) Sukuk ljarah.

Teori inflasi konvensional dalam Karim (2007:135), secara umum inflasi berarti kenaikan tingkat harga secara umum dari barang/komoditas dan jasa selama suatu periode waktu tertentu. Inflasi dapat dianggap sebagai fenomena moneter karena terjadinya penurunan nilai unit perhitungan moneter terhadap suatu komoditas.

Karim (2008:157), menyatakan Nilai tukar vang (exchange rates) atau yang lebih populer dikenal dengan sebutan kurs mata vang adalah catatan (quotation) harga pasar dari mata vang asing (foreign currency) dalam harga mata vang domestik (domestic currency) atau resiprokalnya, yaitu harga mata uang domestik dalam mata vang asing.

Sertifikat Bank Indonesia Syariah (SBIS) adalah surat berharga berdasarkan prinsip syariah berjangka pendek dalam mata vang rupiah yang diterbitkan oleh Bank Indonesia. Sertifikat Bank Indonesia Syariah (SBIS) diterbitkan sebagai salah satu instrumen Operasi Pasar Terbuka dalam rangka pengendalian moneter yang dilakukan berdasarkan prinsip syariah. SBIS diterbitkan dengan memakai akad ju'alah (Hendro, 2014:49-50).

\section{Hubungan Antar Variabel}

1. Pengaruh Inflasi Dengan Pertumbuhan Sukuk

Ardiansyah dan Lubis (2017) meneliti mengenai "Pengaruh Variabel Makroekonomi Terhadap Pertumbuhan Sukuk Korporasi di Indonesia," 
Wahyudi, et al/Jurnal Ekonomi Syariah Teori dan Terapan Vol. 6 No. 3 Maret 2019: 461-476 PENGARUH FAKTOR MAKROEKONOMI TERHADAP TOTAL NILAI EMISI SUKUK KORPORASI DI INDONESIA (PERIODE JANUARI 2013-DESEMBER 2017)

menunjukkan hasil inflasi berpengaruh secara parsial terhadap pertumbuhan sukuk korporasi di Indonesia dan bersifat positif, menyatakan bahwa peningkatan inflasi menyebabkan masyarakat akan memilih untuk mempertahankan nilai vangnya melalui pembelian sukuk korporasi dibandingkan memegang uang yang nilai riilnya akan terus menurun seiring terjadinya peningkatan inflasi. Artinya jika inflasi mengalami kenaikan, maka total nilai emisi sukuk korporasi akan mengalami kenaikan.

Rini (2012) meneliti mengenai "Obligasi Syariah (Sukuk) dan Indikator Makroekonomi Indonesia: Sebuah Analisis Vector Error Correction Model (VECM)," menunjukkan hasil inflasi berpengaruh pada jangka panjang terhadap penerbitan sukuk dan bersifat negatif. Artinya jika inflasi mengalami kenaikan maka total nilai emisi sukuk korporasi akan mengalami penurunan.

2. Nilai Tukar Rupiah Dengan Pertumbuhan Sukuk Korporasi

$$
\text { Manab dan Sujianto (2016) }
$$

meneliti mengenai "Pengaruh Stabilitas Ekonomi Makro Terhadap Penerbitan Sukuk Negara di Indonesia, Malaysia dan Brunei Darussalam," menyatakan variabel kurs berdasarkan hasil pengolahan data sebesar 2.3603. Nilai ini mengandung pengertian bahwa jika kurs berubah sebesar US\$ 1 maka akan berimplikasi terhadap perubahan penerbitan sukuk negara sebesar 2.3603. Notasi positif pada koefisien kurs mencerminkan bahwa kurs memiliki kontribusi positif terhadap penerbitan sukuk negara. Artinya jika nilai tukar rupiah mengalami kenaikan maka total nilai emisi sukuk akan mengalami kenaikan.

3. Pengaruh Imbalan SBIS Dengan Pertumbuhan Sukuk Korporasi

$$
\text { Pada penelitian Rini (2012) }
$$

mengenai "Obligasi Syariah (Sukuk) dan Indikator Makroekonomi Indonesia: Sebuah Analisis Vector Error Correction Model (VECM)," ditemukan hasil bahwa dalam jangka panjang hubungan variabel bonus Sertifikat Bank Indonesia Syariah (SBIS) berpengaruh secara negatif dan signifikan terhadap penerbitan sukuk. Artinya jika imbalan Sertifikat Bank Indonesia Syariah (SBIS) mengalami kenaikan maka total nilai emisi sukuk korporasi akan mengalami penurunan.

\section{Hipotesis}

Hipotesis yang digunakan dalam penelitian ini adalah:

$\mathrm{HI}$ : Inflasi berpengaruh terhadap total nilai sukuk korporasi di Indonesia secara parsial periode Januari 2013-Desember 2017.

H2: Nilai tukar rupiah berpengaruh terhadap total nilai emisi sukuk korporasi secara parsial periode Januari 2013-Desember 2017

H3: Imbalan Sertifikat Bank Indonesia Syariah(SBIS)berpengaruh terhadap total nilai emisi sukuk korporasi secara parsial periode Januari 2013-Desember 2017

H4: Inflasi, nilai tukar rupiah dan imbalan Sertifikat Bank Indonesia Syariah

(SBIS)berpengaruh 
Wahyudi, et al/Jurnal Ekonomi Syariah Teori dan Terapan Vol. 6 No. 3 Maret 2019: 461-476 PENGARUH FAKTOR MAKROEKONOMI TERHADAP TOTAL NILAI EMISI SUKUK KORPORASI DI INDONESIA (PERIODE JANUARI 2013-DESEMBER 2017)

terhadap total nilai emisi sukuk korporasi secara simultan periode Januari 2013-Desember 2017

\section{Model Analisis}

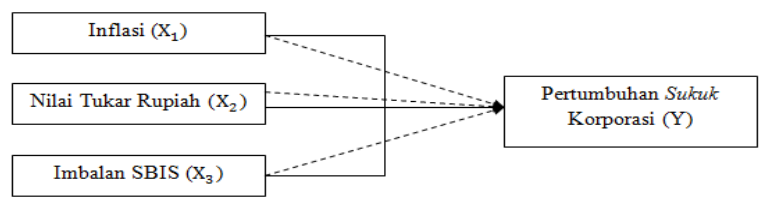

Sumber: Penulis

\section{Gambar 1.}

\section{Model Analisis}

Keterangan:

= seGGra‡arsial

$\longrightarrow$ = secara simultan

Model Pertumbuhan Sukukdengan variabel-variabel tersebut dapat disusun dalam fungsi atau persamaan sebagai berikut:

$Y=\alpha+\beta_{1} X_{1}+\beta_{2} X_{2}+\beta_{3} X_{3}+e$

Keterangan:

$Y=$ Pertumbuhan Sukuk Korporasi

$\alpha=$ Konstanta

$\mathrm{X}_{1}=$ Inflasi

$\mathrm{X}_{2}=$ Nilai Tukar Rupiah

$\mathrm{X}_{3}=$ Imbalan SBIS

$\beta=$ Koefisien Regresi

e $=$ Error Term

\section{METODE PENELITIAN}

\section{Pendekatan Penelitian}

Pendekatan penelitian yang digunakan adalah pendekatan kuantitatif. Menurut Sugiyono (2011:8), metode penelitian kuantitatif dapat diartikan sebagai metode penelitian yang berlandaskan pada filsafat positivisme, digunakan untuk meneliti pada populasi atau sampel tertentu, pengumpulan data menggunakan instrumen penelitian, analisis data bersifat statistik dengan tujuan untuk menguji hipotesis yang telah ditetapkan.

\section{Identifikasi Variabel}

Penelitian ini menggunakan dua jenis variabel, yaitu variabel independen dan dependen. Variabel independen dalam penelitian ini adalah Inflasi, Nilai Tukar Rupiah dan Imbalan SBIS, sedangkan variabel dependen dalam penelitian ini adalah varibel yang kondisinya dipengaruhi variabel independen. Variabel dependen dalam penelitian ini adalah pertumbuhan sukuk korporasi di Indonesia periode Januari 2013-Desember 2017.

\section{Definisi Operasional}

Definisi operasional dari masingmasing variabel yang digunakan dalam penelitian ini adalah sebagai berikut:

1. Inflasi $\left(X_{1}\right)$ didefinisikan sebagai meningkatnya harga-harga secara umum dan terus menerus. Kenaikan harga dari satu atau dua barang saja tidak dapat disebut inflasi kecuali bila kenaikan itu meluas (atau mengakibatkan kenaikan harga) pada barang lainnya. Indikator yang digunakan untuk mengukur tingkat inflasi adalah Indeks Harga konsumen (IHK). Data inflasi merupakan data nasional secara bulanan dipublikasikan oleh Bank Indonesia periode Januari 2013-Desember 2017.

2. Nilai Tukar Rupiah $\left(\mathrm{X}_{2}\right)$ didefinisikan sebagai nilai tukar atau yang lebih populer dikenal dengan sebutan kurs mata vang adalah catatan 
Wahyudi, et al/Jurnal Ekonomi Syariah Teori dan Terapan Vol. 6 No. 3 Maret 2019: 461-476 PENGARUH FAKTOR MAKROEKONOMI TERHADAP TOTAL NILAI EMISI SUKUK KORPORASI DI INDONESIA (PERIODE JANUARI 2013-DESEMBER 2017)

(quotation) harga pasar dari mata vang asing (foreign currency) dalam harga mata vang domestik (domestic currency) atau resiprokalnya, yaitu harga mata vang domestik dalam mata vang asing (Karim, 2008:157). Data nilai tukar merupakan data nasional secara bulanan dipublikasikan oleh kemendag periode Januari 2013Desember 2017.

3. Imbalan Sertifikat Bank Indonesia Syariah (SBIS) $\left(\mathrm{X}_{3}\right)$ adalah instrumen Bank Indonesia yang sesuai dengan syariah islam yang digunakan dalam operasi pasar terbuka syariah. Tingkat imbalan yang diberikan mengacu kepada diskonto hasil lelang SBI berjangka waktu sama yang diterbitkan bersamaan dengan penerbitan SBIS. Data imbalan SBIS merupakan data nasional secara bulanan yang dipublikasikan oleh Bank Indonesia periode Januari 2013Desember 2017.

4. Total Nilai Emisi Sukuk Korporasi, dimana total nilai emisi sukuk korporasi adalah penjumlahan emisi sukuk yang masih beredar (outstanding) dan nilai emisi sukuk yang sudah dilunasi. Data total nilai emisi sukuk korporasi merupakan data nasional secara bulanan yang dipublikasikan oleh Otoritas Jasa Keuangan (OJK) pada periode Januari 2013 sampai Desember 2017.

\section{Jenis dan Sumber Data}

Data yang digunakan dalam penelitian ini adalah data sekunder yang terukur secara runtun waktu (time series).
Data sekunder meliputi inflasi, nilai tukar rupiah, imbalan SBIS dan total nilai emisi sukuk korporasi. Pada penelitian ini data sekunder bersumber dari website resmi Bank Indonesia, kemendag, dan OJK periode Januari 2013-Desember 2017.

\section{Populasi dan Sampel}

Populasi yang digunakan pada penelitian ini adalah sukuk korporasi yang dipublikasikan situs resmi OJK di Indonesia periode Januari 2013-Desember 2017.

Metode pemilihan sampel yang digunakan dalam penelitian ini adalah purposive sampling. Purposive sampling adalah teknik penentuan sampel dengan pertimbangan tertentu (Anshori dan Iswati, 2009:105). Berdasarkan metode tersebut, maka sampel yang digunakan dalam penelitian ini adalah total nilai emisi sukuk korporasi di Indonesia periode Januari 2013 sampai Desember 2017 di Indonesia yang dipublikasikan oleh situs resmi Otoritas Jasa Keuangan (OJK).

\section{Teknik Analisis}

Penelitian ini menggunakan teknikanalisis regresi linier berganda dengan menggunakan program SPSS 20 untuk melakukan pengujian datanya. Pengujian data menggunakan uji asumsi klasik, yaitu berupa uji normalitas, uji multikolinieritas,uji heteroskedastisitas, dan ujiautokorelasi. Setelah itu, dilakukan pengujian koefisien determinasi (R2) dan uji hipotesis. Uji hipotesis meliputi uji $\mathrm{F}$ yang digunakan untuk mengetahui pengaruh variabelindependen terhadap variabel dependensecara simultan, dan uji $\dagger$ dilakukan untuk mengetahui pengaruh 
Wahyudi, et al/Jurnal Ekonomi Syariah Teori dan Terapan Vol. 6 No. 3 Maret 2019: 461-476 PENGARUH FAKTOR MAKROEKONOMI TERHADAP TOTAL NILAI EMISI SUKUK KORPORASI DI INDONESIA (PERIODE JANUARI 2013-DESEMBER 2017)

variabel independen terhadap variabel dependen secara parsial.

\section{HASIL DAN PEMBAHASAN}

1. Deskripsi Inflasi

Nilai maksimum yang dicapai oleh inflasi terjadi pada periode Agustus 2013 yaitu sebesar $8.79 \%$, sedangkan nilai minimum yang diperoleh sebesar $2.79 \%$ yang terjadi pada periode Agustus 2016. Rata-rata variabel inflasi selama periode penelitian sebesar $5.42 \%$.

2. Deskripsi Nilai Tukar Rupiah

Nilai maksimum yang dicapai oleh nilai tukar rupiah terjadi pada periode September 2015 sebesar 14,657.00, sedangkan nilai minimum yang diperoleh sebesar 9,667.00 yang terjadi pada periode Februari 2013. Rata-rata variabel nilai tukar rupiah selama periode penelitian sebesar 12,526.00.

\section{Deskripsi Imbalan SBIS}

Nilai maksimum yang dicapai oleh imbalan SBIS terjadi pada periode Januari 2014 yaitu sebesar $7.23 \%$, sedangkan nilai minimum yang diperoleh sebesar $4.84 \%$ yang terjadi pada periode Januari 2013. Rata-rata variabel imbalan SBIS selama periode penelitian sebesar $6.34 \%$.

4. Deskripsi total nilai emisi sukuk korporasi

Nilai maksimum yang dicapai oleh total nilai emisi sukuk korporasi terjadi pada periode Desember 2017 yaitu sebesar 26,394.90, sedangkan nilai minimum yang diperoleh sebesar 9,790.40 yang terjadi pada periode Januari 2013. Rata-rata variabel total nilai emisi sukuk korporasi selama periode penelitian sebesar 15,944.66

\section{Pengujian Asumsi Klasik}

1. Uji Normalitas

Uji normalitas digunakan untuk menguji apakah dalam regresi variabel pengganggu atau residualnya memiliki distribusi normal . Uji normalitas dapat dilakukan dengan menggunakan dua cara, yaitu menganalisis gambar Normal P-P Plot dan melakukan uji statistik.

Analisis gambar Normal P-P Plot dilakukan dengan melihat apakah titik-titik yang terdapat dalam gambar mengikuti sumbu diagonalnya. Apabila titiktitiktersebut mengikuti sumbu diagonalnya, maka data berdistribusi normal. Hasil pengujian Normal P-P Plot dapat dilihat pada Gambar 2 berikut.

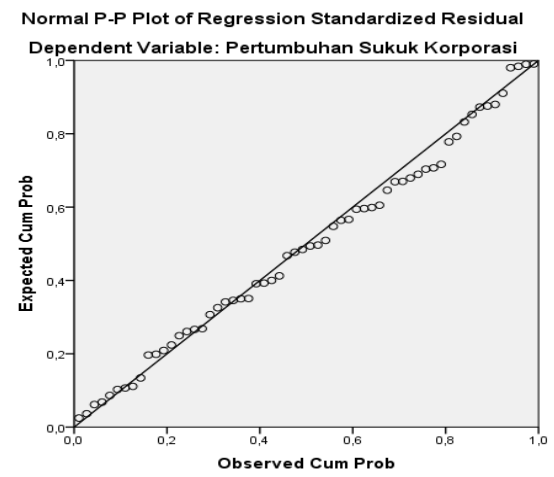

Sumber: hasil uji SPSS 20

\section{Gambar 2.}

\section{Uji Normal P-P Plot}

Berdasarkan Gambar 2 terlihat bahwa titik-titik menyebar mengikuti sumbu diagonalnya, sehingga model regresi lolos uji normalitas.

Uji statistik dilakukan dengan menggunakan besaran KolmogorovSmirnov. Apabila signifikansi dari masingmasing variabel lebih dari 0.05, maka data berdistribusi normal (Sujarweni, 2014:55). 
Wahyudi, et al/Jurnal Ekonomi Syariah Teori dan Terapan Vol. 6 No. 3 Maret 2019: 461-476 PENGARUH FAKTOR MAKROEKONOMI TERHADAP TOTAL NILAI EMISI SUKUK KORPORASI DI INDONESIA (PERIODE JANUARI 2013-DESEMBER 2017)

Hasil uji Kolmogorov-Smirnov dapat dilihat pada tabel 3 berikut.

Tabel 3.

Uji Normalitas Kolmogorov-Smirnov

\begin{tabular}{|c|c|c|}
\hline Nilai asymp, Sig, (2-tailed) & A & Kesimpulan \\
\hline 0.856 & $5 \%$ ataul 0.05 & $\begin{array}{l}\text { Residual mengikuti pola } \\
\text { distribusi nomal }\end{array}$ \\
\hline
\end{tabular}

Sumber: Hasil Uji SPSS 20

$$
\text { Berdasarkan Tabel } 3 \text { dapat }
$$

disimpulkan data yang digunakan

berdistribusi normal.

2. Uji Multikolinieritas

Uji multikolinearitas ini digunakan untuk mengetahui adanya hubungan atau korelasi antar masing-masing variabel dalam penelitian ini. Cara mengetahui masingmasing variabel eksogen dari multikolinearitas dapat diukur dari VIF (Variance Inflation Factor) dan tolerance value. Batasan yang digunakan adalah VIF kurang dari 10 dan tolerance value lebih dari 0.10 , Tabel 4 menunjukkan hasil dari uji multikolinieritas.

Tabel 4.

Hasil Uji Multikolinieritas

\begin{tabular}{|c|c|c|c|c|}
\hline \multirow{2}{*}{ Variabel } & \multicolumn{2}{|c|}{ Collinerity Statistik } & Interpretasi & \\
\cline { 2 - 3 } & Tolerance & VIF & Hasil & Keterangan \\
\hline Inflasi $\left(\mathrm{X}^{1}\right)$ & 0.522 & 1.915 & $\begin{array}{c}\text { Nilai tolerance } \\
>0.10, \text { Nilai } \\
\text { VIF }<10\end{array}$ & $\begin{array}{c}\text { Bebas } \\
\text { multikolinearitas }\end{array}$ \\
\hline $\begin{array}{c}\text { Nilai Tukar } \\
\text { Rupiah }\left(\mathrm{X}^{2}\right)\end{array}$ & 0.559 & 1.790 & $\begin{array}{c}\text { Nilai tolerance } \\
>0.10, \text { Nilai } \\
\text { VIF }<10\end{array}$ & $\begin{array}{c}\text { Bebas } \\
\text { multikolinearitas }\end{array}$ \\
\hline $\begin{array}{c}\text { Imbalan SBIS } \\
\left(\mathrm{X}^{3}\right)\end{array}$ & 0.543 & 1.843 & $\begin{array}{c}\text { Nilai tolerance } \\
>0.10, \text { Nilai } \\
\text { VIF }<10\end{array}$ & $\begin{array}{c}\text { Bebas } \\
\text { multikolinearitas }\end{array}$ \\
\hline
\end{tabular}

Sumber: Hasil Uji SPSS 20

3. Uji Heteroskedastisitas

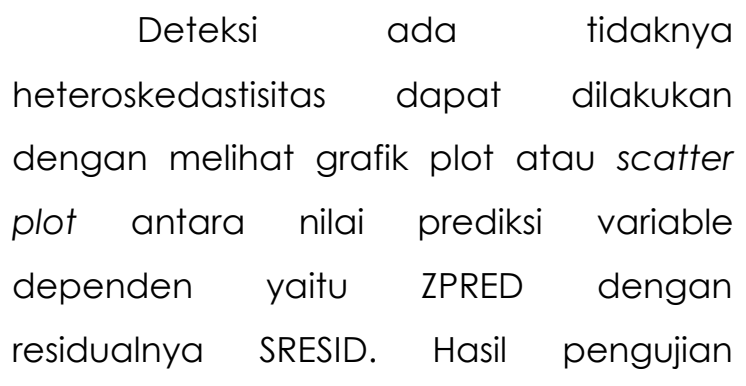

heteroskedastisitas dapat dilihat pada Gambar 5 berikut.

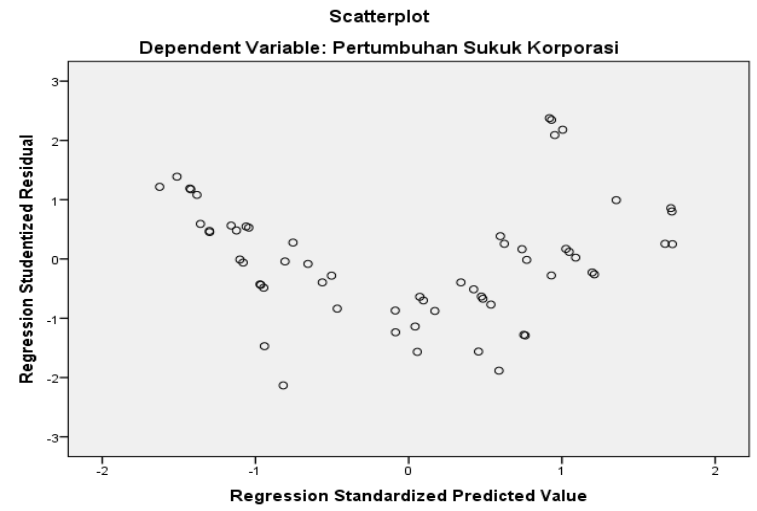

Sumber: Hasil Uji SPSS 20

Gambar 3.

\section{Hasil Uji Heteroskedastisitas}

Terlihat pada Gambar 5 bahwa pola dalam grafik scatterplot menyebar diatas dan dibawah angka 0 pada sumbu $Y$, sehingga tidak terjadi heteroskedastisitas dalam model regresi penelitian ini.

4. Uji Autokolerasi

Hubungan antar variabel dalam penelitian yang menggunakan teknik analisis regresi linier berganda harus terbebas dari masalah autokorelasi. Uji autokorelasi salah satunya dapat menggunakan metode uji Durbin Watson. Apabila angka D-W di antara -2 sampai +2, berarti tidak ada autokorelasi (Santoso, 2000:219).

Tabel 5.

Hasil Uji Autokolerasi Durbin-Watson

\begin{tabular}{|c|c|c|}
\hline Nilai D-W & $\begin{array}{c}\text { Interpretasi } \\
\text { Hasil }\end{array}$ & keterangan \\
\hline 0.340 & $-2<\mathrm{D}-\mathrm{W}>+2$ & $\begin{array}{c}\text { Tidak terjadi } \\
\text { Autokolerasi }\end{array}$ \\
\hline
\end{tabular}

Sumber: Hasil Uji SPSS 20 
Wahyudi, et al/Jurnal Ekonomi Syariah Teori dan Terapan Vol. 6 No. 3 Maret 2019: 461-476 PENGARUH FAKTOR MAKROEKONOMI TERHADAP TOTAL NILAI EMISI SUKUK KORPORASI DI INDONESIA (PERIODE JANUARI 2013-DESEMBER 2017)

Analisis Koefisien Determinasi dan

\section{Pengujian Hipotesis}

Hasil uji koefisien determinasi dapat dilihat pada Tabel 6 berikut:

Tabel 6.

Hasil Uji Koefisien Determinasi

\begin{tabular}{|c|c|c|c|c|}
\hline Model & $R$ & R Square & $\begin{array}{c}\text { Adjusted } \\
\text { R Square }\end{array}$ & $\begin{array}{c}\text { Std. Eror of } \\
\text { The Estimate }\end{array}$ \\
\hline 1 & $0.918^{\mathrm{a}}$ & 0.844 & 0.835 & 0.11662 \\
\hline
\end{tabular}

Sumber: Hasil Uji SPSS 20

Berdasarkan Tabel 6 dapat dilihat bahwa hasil uji $\mathrm{R}^{2}$ sebesar 0.844 atau $84.40 \%$, dengan kata lain $84.40 \%$ pertumbuhan sukuk korporasi dipengaruhi oleh variabel inflasi, nilai tukar rupiah dan imbalan SBIS, sedangkan sisanya sebesar $15.60 \%$ dipengaruhi oleh faktor lain diluar model penelitian.

Pengujian hipotesis dilakukan dengan dua teknik uji, yaitu uji F dan uji t.

Tabel 7.

Hasil uji F

\begin{tabular}{|c|c|c|}
\hline Sig. & Interpretasi & Keterangan \\
\hline 0.000 & Sig. $<\alpha(0.000<$ & $\mathrm{H}_{0}$ ditolak \\
& $0.05)$ & \\
\hline
\end{tabular}

Sumber: Hasil Uji SPSS 20

Berdasarkan Tabel 7, Sig. $<\alpha$ $(0.000<0.05)$ sehingga $\mathrm{H}_{0}$ ditolak. Berdasarkan hasil pengolahan data dapat disimpulkan bahwa inflasi, nilai tukar rupiah dan imbalan SBIS secara simultan berpengaruh signifikan terhadap total nilai emisi sukuk korporasi di Indonesia.
Tabel 8.

Hasil Uji $†$

\begin{tabular}{|c|c|c|c|c|c|}
\hline \multirow{2}{*}{ Model } & \multicolumn{2}{|l|}{ Unstandardized Coefficients } & $\begin{array}{c}\text { Standardized } \\
\text { Coefficients }\end{array}$ & \multirow{2}{*}{$\mathrm{t}$} & Sig. \\
\cline { 2 - 4 } & $\mathrm{B}$ & Std. Error & Beta & & \\
\hline (Constant) & 11.680 & 1.724 & & 6.774 & 0.000 \\
\hline Inflasi & -0.029 & 0.011 & -0.187 & -2.558 & 0.013 \\
\hline $\begin{array}{c}\text { Nilai Tukar } \\
\text { Rupiah }\end{array}$ & 2.129 & 0.189 & 0.795 & 11.244 & 0.000 \\
\hline $\begin{array}{c}\text { Imbalan } \\
\text { SBIS }\end{array}$ & -0.196 & 0.028 & -0503 & -7.016 & 0.000 \\
\hline
\end{tabular}

Sumber: Hasil Uji SPSS 20

Berdasarkan hasil uji † pada Tabel 8 dapat dilihat pengaruh masing-masing variabel secara parsial. Apabila nilai signifikansi lebih kecil dari $\alpha(0.05)$, makaH $_{0}$ ditolak. Berdasarkan hasil tersebut dapat disimpulkan bahwa secara parsial inflasi, nilai tukar rupiah, imbalan SBIS secara parsial berpengaruh signifikan terhadap pertumbuhan sukuk korporasi di Indonesia.

\section{Pembahasan}

Pengaruh Inflasi Terhadap Pertumbuhan Sukuk Korporasi di Indonesia Secara Parsial

Berdasarkan hasil pengolahan data uji $\dagger$ diketahui bahwa signifikansi pada variabel inflasi sebesar 0.013 dimana nilai ini lebih kecil dari $\alpha(0.013<0.05)$, sehingga $\mathrm{H}_{0}$ ditolak dan bernilai negatif yaitu -2.558. Hal ini menunjukkan bahwa inflasi secara parsial berpengaruh secara signifikan dan negatif terhadap pertumbuhan sukuk korporasi di Indonesia.

Fenomena inflasi yang ditandai dengan melonjaknya harga dan menurunnya daya beli masyarakat yang terjadi karena tingkat pendapatan masyarakat tidak mengalami peningkatan, maka inflasi juga berimbas pada perusahaan. Karena harga yang terus melambung namun pendapatan 
Wahyudi, et al/Jurnal Ekonomi Syariah Teori dan Terapan Vol. 6 No. 3 Maret 2019: 461-476 PENGARUH FAKTOR MAKROEKONOMI TERHADAP TOTAL NILAI EMISI SUKUK KORPORASI DI INDONESIA (PERIODE JANUARI 2013-DESEMBER 2017)

masyarakat yang tetap sehingga menurunkan daya beli masyarakat. Inflasi yang tinggi menyebabkan naiknya harga bahan produksi sehingga biaya produksi akan mengalami kenaikan hingga pada akhirnya merugikan perusahaan.

Perusahaan akan lebih memilih untuk tidak menerbitkan surat hutang berupa sukuk karena pada saat inflasi mengalami kenaikan, profitabilitas perusahaan akan mengalami penurunan akibat dari biaya produksi yang bertambah, karena ketika inflasi tinggi menyebabkan harga bahan baku mengalami kenaikan. Perusahaan akan terbebani ketika menerbitkan surat hutang berupa sukuk pada saat kondisi inflasi tinggi karena harus memberikan bagi hasil kepada investor sedangkan profitabilitas yang diterima perusahaan menurun. Ketika inflasi mengalami peningkatan maka perusahaan akan lebih memilih melakukan penambahan modal dengan melakukan pinjaman pada perbankan untuk biaya operasional perusahaannya, karena tidak ingin terbebani dengan bagi hasil kepada investor pada saat profitabilitas perusahaan menurun. Sehingga ketika inflasi mengalami kenaikan maka akan menurunkan total nilai emisi sukuk korporasi

Hasil pada penelitian ini mendukung penelitian Rini (2012) yang menyatakan ketika inflasi mengalami kenaikan maka penerbitan sukuk akan mengalami penurunan yang diakibatkan kondisi makroekonomi domestik dalam keadaan tidak baik. Hal ini dikarenakan pemerintah dan korporasi selaku emiten akan melihat dan menyesuaikan jumlah sukuk yang diterbitkan dengan kondisi pasar yang terjadi.

\section{Pengaruh Nilai Tukar Rupiah Terhadap Per} tumbuhan Sukuk Korporasi di Indonesia secara parsial

Berdasarkan hasil pengolahan data uji $\dagger$ diketahui bahwa signifikansi pada variabel inflasi sebesar 0.000 dimana nilai ini lebih kecil dari $\alpha(0.000<0.05)$, sehingga $\mathrm{H}_{0}$ ditolak dan bernilai positif yaitu 11.244. Hal ini menunjukkan bahwa inflasi secara parsial berpengaruh secara signifikan dan positif terhadap pertumbuhan sukuk korporasi di Indonesia.

Nilai tukar rupiah terhadap USD merupakan salah satu variabel yang mampu mempengaruhi total nilai emisi sukuk korporasi pada pasar modal syariah secara searah pada perusahaanperusahaan dalam kategori perusahaan impor maupun ekspor. Nilai tukar rupiah yang mengalami penurunan terhadap USD akan memberikan dampak yang searah bagi perusahaan yang menggunakan bahan baku impor, perusahaan akan menanggung biaya yang lebih tinggi dari sebelumnya karena nilai mata uang rupiah yang mengalami penurunan dengan adanya peningkatan biaya, pendapatan dari perusahaan akan mengalami penurunan dengan tingkat produksi yang sama. Perusahaan yang memiliki hutang dalam mata uang USD akan menanggung kewajiban pembayaran yang lebih besar karena 
Wahyudi, et al/Jurnal Ekonomi Syariah Teori dan Terapan Vol. 6 No. 3 Maret 2019: 461-476 PENGARUH FAKTOR MAKROEKONOMI TERHADAP TOTAL NILAI EMISI SUKUK KORPORASI DI INDONESIA (PERIODE JANUARI 2013-DESEMBER 2017)

mata vang rupiah mengalami penurunan. Apabila laba perusahaan menurun maka perusahaan lebih memilih untuk tidak menerbitkan surat hutang berupa sukuk karena perusahaan tidak ingin menambah beban dengan memberikan bagi hasil kepada investor. Sehingga ketika nilai tukar rupiah mengalami penurunan maka akan menurunkan total nilai emisi sukuk korporasi

Sebaliknya apabila nilai tukar rupiah yang mengalami kenaikan terhadap USD akan memberikan dampak yang searah bagi perusahaan ekspor, dimana tingkat ekspor akan meningkat akibat dari rupiah mengalami kenaikan terhadap USD. Momen peningkatan nilai tukar rupiah akan dimanfaatkan oleh perusahaan untuk lebih banyak melakukan kegiatan usahanya, perusahaan akan lebih banyak menerbitkan surat hutang berupa sukuk untuk penambahan modal karena perusahaan eksportir ketika nilai tukar rupiah mengalami kenaikan secara langsung akan menaikkan profitabilitas perusahaannya, sehingga bagi hasil untuk investor tidak akan menjadi beban bagi perusahaan dengan profitabilitas yang besar. Sehingga ketika nilai tukar rupiah mengalami kenaikan maka akan menaikkan total nilai emisi sukuk korporasi

Hasil pada penelitian ini mendukung penelitian Manab dan Sujianto (2016) yang menyatakan Kurs mata uang domestik terhadap dollar Amerika Serikat sangat sensitif terhadap penerbitan sukuk negara. Pada saat kurs menguat (apresiasi) maka penerbitan sukuk negara mengalami pertumbuhan dan ketika terjadi depresiasi kurs maka penerbitan sukuk negara turun.

\section{Pengaruh Imbalan SBIS Terhadap Pertumbuhan Sukuk Korporasi di Indonesia Secara Parsial}

Berdasarkan hasil pengolahan data uji $\dagger$ diketahui bahwa signifikansi pada variabel inflasi sebesar 0.000 dimana nilai ini lebih kecil dari $\alpha(0.000<0.05)$, sehingga $\mathrm{H}_{0}$ ditolak dan bernilai negatif yaitu -7.016. Hal ini menunjukkan bahwa inflasi secara parsial berpengaruh secara signifikan dan negatif terhadap pertumbuhan sukuk korporasi di Indonesia.

Sertifikat Bank Indonesia Syariah (SBIS) menurut peraturan Bank Indonesia No 10/11/PBI/2008 tentang Sertifikat Bank Indonesia Syariah adalah surat berharga berdasarkan prinsip syariah berjangka waktu pendek dalam mata vang rupiah yang diterbitkan oleh Bank Indonesia. Perhitungan besar bonus yang diberikan pada SBIS maengacu pada tingkat diskonto hasil lelang SBI berjangka waktu sama yang diterbitkan bersamaan dengan penerbitan SBIS.

Sertifikat Bank Indonesia Syariah (SBIS) menjadi alternatif bagi perusahaan dalam penambahan modal untuk usahanya dimasa mendatang yang berasal dari imbalan atas investasi dalam Sertifikat Bank Indonesia Syariah (SBIS). Tingginya imbalan yang diberikan oleh Sertifikat Bank Indonesia akan menarik perusahaan untuk lebih mengalokasikan dananya dalam investasi SBIS sebagai sarana 
Wahyudi, et al/Jurnal Ekonomi Syariah Teori dan Terapan Vol. 6 No. 3 Maret 2019: 461-476 PENGARUH FAKTOR MAKROEKONOMI TERHADAP TOTAL NILAI EMISI SUKUK KORPORASI DI INDONESIA (PERIODE JANUARI 2013-DESEMBER 2017)

dalam mengamankan modal usahanya serta keberlangsungan perusahaan pada masa yang akan datang dari pada harus menerbitkan surat hutang berupa sukuk yang akan menambah beban perusahaan karena harus memberikan bagi hasil kepada investor. Sehingga ketika imbalan Sertifikat Bank Indonesia Syariah (SBIS) mengalami kenaikan maka akan menurunkan total nilai emisi sukuk korporasi.

$$
\text { Hasil pada penelitian ini }
$$
mendukung penelitian Rini (2012) yang menyebutkan bahwa dalam jangka panjang hubungan variabel bonus SBIS berpengaruh secara negatif dan signifikan terhadap penerbitan sukuk.

Pengaruh Inflasi, Nilai Tukar Rupiah dan Imbalan SBIS Terhadap Pertumbuhan Sukuk Korporasi di Indonesia Secara Simultan

Uji F digunakan untuk menunjukkan apakah semua variabel independen yang ada dalam penelitian mempunyai pengaruh secara bersama-sama terhadap variabel dependen. Dasar pengambilan keputusannya adalah dengan membandingkan nilai $F_{\text {hitung }}$ lebih besar dari nilai $F_{\text {tabel }}$ dan nilai signifikansi lebig kecil dari nilai $\alpha=0.05(0.000<0.05)$, maka dapat disimpulkan bahwa terdapat pengaruh yang signifikan secara simultan antara variabel inflasi, nilai tukar rupiah dan imbalan SBIS terhadap total nilai emisi sukuk korporasi di Indonesia.

Inflasi, nilai tukar rupiah dan imbalan SBIS memberikan pengaruh sebesar 84.40 persen terhadap total nilai emisi sukuk korporasi yang ditunjukkan dengan koefisien determinasi $\left(\mathrm{R}^{2}\right)$ sebesar 0.844. Hal ini menunjukkan bahwa total nilai emisi sukuk korporasi 15.60 persen nya dipengaruhi oleh faktor-faktor lain yang tidak diteliti.

\section{v. SIMPULAN}

Hasil analisis dan pembahasan dapat disimpulkan sebagai berikut:

1. Inflasi secara parsial memiliki pengaruh yang signifikan terhadap total nilai emisi sukuk korporasi di Indonesia periode Januari 2013-Desember 2017 dengan koefisien regresi sebesar 0.013 dan memiliki pengaruh negatif yang ditunjukkan oleh uji † sebesar -2.558 .

2. Nilai tukar rupiah secara parsial memiliki pengaruh yang signifikan terhadap total nilai emisi sukuk korporasi di Indonesia periode Januari 2013-Desember 2017 dengan koefisien regresi sebesar 0.000 dan memiliki pengaruh positif yang ditunjukkan oleh uji $\dagger$ sebesar 11.244 .

3. Imbalan Sertifikat Bank Indonesia Syariah (SBIS) secara parsial memiliki pengaruh yang signifikan terhadap total nilai emisi sukuk korporasi di Indonesia periode Januari 2013Desember 2017 dengan koefisien regresi sebesar 0.000 dan memiliki pengaruh negatif yang ditunjukkan oleh uji t sebesar -7.016

4. Secara simultan seluruh variabel independen berpengaruh signifikan terhadap total nilai emisi sukuk korporasi di Indonesia periode Januari 2013-Desember 2017 sebesar 84.40\% 
Wahyudi, et al/Jurnal Ekonomi Syariah Teori dan Terapan Vol. 6 No. 3 Maret 2019: 461-476 PENGARUH FAKTOR MAKROEKONOMI TERHADAP TOTAL NILAI EMISI SUKUK KORPORASI DI INDONESIA (PERIODE JANUARI 2013-DESEMBER 2017)

pertumbuhan sukuk korporasi dapat dijelaskan oleh inflasi, nilai tukar rupiah dan imbalan SBIS, sedangkan sisanya sebesar $15.60 \%$ dijelaskan oleh variabel lain.

\section{DAFTAR PUSTAKA}

Anshori, Muslich dan Sri Iswati. 2009. Buku Ajar Metodologi Penelitian Kuantitatif. Surabaya: Pusat Penerbitan dan Percetakan Unair (AUP).

Ardiansyah, IH dan Lubis D. 2017. The effect of Macroeconomic Varibles to Corporate Sukuk Growth in Indonesia. Jurnal Al Muzara'ah, Vol. 5 No.1, 2017/ISSN p:2337 6333; e: 2355-4363).

Bakri, Syaiful. 2004. Analisis Faktor-Faktor yang Mempengaruhi Harga Saham (Studi Kasus Perusahaan Terdaftar di JII). Tesis. Jakarta:

Pasca Sarjana PIKTI-UI.

Dewan Syariah Nasional. 2003. Fatwa DSN MUI Nom: 40/DSN-MUI/X/2003 Tentang Pasar Modal dan Pedoman Umum Penerapan Prinsip Syariah di Bidang Pasar Modal. (online) www.dsnmui.or.id. diakses pada 25 Maret 2018.

Hidayat, Taufik. 2011. Buku Pintar Investasi Syariah. Jakarta: Mediakita.

Karim, Adiwarman A. 2007. Ekonomi Makro Islam, Edisi kedua. Jakarta: PT Raja Grafindo Persada. 2008. Ekonomi Makro Islam. Jakarta: PT Raja Grafindo Persada. Kholis, Nur. 2010. Sukuk: Instrumen Investasi yang Halal dan Menjanjikan.
La_Riba Jurnal Ekonomi Islam, Vol. IV No. 2, Desember 2010

Manab, Abdul dan Sujianto Agus Eko. 2016. Pengaruh Stabilitas Ekonomi Makro Terhadap Penerbitan Sukuk Negara di Indonesia, Malaysia dan Brunai Darussalam. Tulungagung: Cahaya Abadi.

Manan, Abdul. 2010. Aspek Hukum dalam Penyelenggaraan Investasi di Pasar Modal Syariah Indonesia. Jakarta: KENCANA.

Mankiw, N. Gregory. 2007. Makroekonomi, Edisi keenam. Jakarta: Erlangga.

Putong, Iskandar. 2003. Pengantar: Ekonomi Mikro \& Makro, Edisi kedua. Jakarta: Ghalia Indonesia.

Rini, Mustika. 2012. Obligasi Syariah (Sukuk) dan Indikator Makroekonomi Indonesia: Sebuah Analisis Vector Error Correction Model (VECM). Skripsi. Bogor: Institut Pertanian Bogor.

Rodoni dan Herni Ali, Ahmad. 2010. Manajemen Keuangan, Edisi 1. Jakarta: Wacana Media.

Ryandono, Muhamad Nafik H. 2009. Bursa Efek dan Investasi Syariah. Jakarta: Serambi llmu Semesta.

Santoso, Singgih. 2000. BukU Latihan SPSS: Statistik Parametrik. Elex Media Komputindo.

Sugiyono. 2011. Metode Penelitian Kuantitatif Kualitatif dan R\&D. Bandung: ALFABETA.

Sujarweni, V. Wiratma. 2014. SPSS untuk Penelitian. Yogyakarta: Pustaka Baru Press. 
Wahyudi, et al/Jurnal Ekonomi Syariah Teori dan Terapan Vol. 6 No. 3 Maret 2019: 461-476 PENGARUH FAKTOR MAKROEKONOMI TERHADAP TOTAL NILAI EMISI SUKUK KORPORASI DI INDONESIA (PERIODE JANUARI 2013-DESEMBER 2017)

Wahid, Nazzarudin Abdul. 2010. Sukuk:

$\begin{array}{ll}\text { Memahami } & \text { dan Membedah } \\ \text { Obligasi } & \text { pada Perbankan } \\ \text { Syariah. } & \text { Yogyakarta: } \\ \text { Kanisius. } & \end{array}$

http://www.bi.go.id/id/moneter/inflasi/dat

a/Default.aspx (Diakses Pada oktober 2017)

https://www.bi.go.id/id/moneter/operasi//

elang-

sbi/Pages/SBIS_15122017.aspx

(Diakses Pada Oktober 2017)

http://www.kemendag.go.id/id/economi

c-profile/economic-

indicators/exchange-rates (Diakses

Pada Oktober 2017)

https://www.ojk.go.id/id/kanal/syariah/da

ta-dan-statistik/data-produk-

obligasi-syariah/Default.aspx

(Diakses Pada Oktober 2017). 